\title{
Single nucleotide polymorphisms as prognostic and predictive biomarkers in renal cell carcinoma
}

\author{
Carmen Garrigós ${ }^{1}$, Marta Espinosa $^{1}$, Ana Salinas ${ }^{1}$, Ignacio Osman², Rafael Medina $^{2}$, \\ Miguel Taron ${ }^{1}$, Sonia Molina-Pinelo ${ }^{1,3}$ and Ignacio Duran ${ }^{1}$ \\ ${ }^{1}$ Instituto de Biomedicina de Sevilla, IBiS, Hospital Universitario Virgen del Rocío, CSIC, Universidad de Sevilla, Sevilla, Spain \\ ${ }^{2}$ Unidad de Urología Oncológica, UGC Urología-Nefrología H.U.Virgen del Rocío, Instituto de Biomedicina de Sevilla, IBiS, \\ Hospital Universitario Virgen del Rocío, CSIC, Universidad de Sevilla, Sevilla, Spain \\ ${ }^{3}$ Centro de Investigación Biomédica en Red Cáncer, CIBERONC, Madrid, Spain
}

Correspondence to: Ignacio Duran, email: ignacioduranmartinez@gmail.com

Keywords: single nucleotide polymorphisms; angiogenesis genes; biomarkers; localized renal cell carcinoma; advanced renal cell carcinoma

Received: May 13, $2017 \quad$ Accepted: October 25, $2017 \quad$ Published: November 20, 2017

Copyright: Garrigós et al. This is an open-access article distributed under the terms of the Creative Commons Attribution License 3.0 (CC BY 3.0), which permits unrestricted use, distribution, and reproduction in any medium, provided the original author and source are credited.

\section{ABSTRACT}

Despite major advances in the knowledge of the molecular basis of renal cell carcinoma, prognosis is still defined using clinical and pathological parameters. Moreover, no valid predictive biomarkers exist to help us selecting the best treatment for each patient. With these premises, we aimed to analyse the expression and to determine the prognostic and predictive value of $64 \mathrm{key}$ single nucleotide polymorphisms in $\mathbf{1 8}$ genes related with angiogenesis or metabolism of antiangiogenics in two cohorts of patients with localized and advanced renal cell cancer treated at our institution. The presence of the selected single nucleotide polymorphisms was correlated with clinical features, disease free survival, overall survival and response rate. In patients with localized renal cell cancer, 5 of these polymorphisms in 3 genes involved in angiogenesis predicted for worse disease free survival (VEGFR2: rs10013228; PDGFRA: rs2228230) or shorter overall survival (VEGFR2: rs10013228; VEGFR3: rs6877011, rs307826) $(p<0.05)$. Rs2071559 in VEGFR2 showed a protective effect $(p=0.01)$. In the advanced setting, 5 SNPs determined inferior overall survival (IL8: rs2227543, PRKAR1B: rs9800958, PDGFRB: rs2302273; $p=0.05$ ) or worse response rate (VEGFA: rs699947, rs3025010 $p \leq 0.01)$ ). Additionally 1 single nucleotide polymorphism in VEGFB predicted for better response rate rs594942 $(p=0.03)$. Genetic analysis of renal cell carcinoma patients might provide valuable prognostic/predictive information. A set of SNPs in genes critical to angiogenesis and metabolism of antiangiogenics drugs seem to determine post-surgical outcomes and treatment response in our series.

\section{INTRODUCTION}

Renal cell carcinoma (RCC) is the most common malignancy of the kidney with near 338.000 new diagnoses per year worldwide [1]. It is more frequent in men and $75 \%$ of the patients are diagnosed over 60 years of age. Incidence of RCC has increased steadily at $2 \%$ per year contributing to about 144.000 deaths in 2012 $[2,3]$. Diverse histological variants have been described including clear cell (75\%), papillary (10\%), chromophobe
(5\%) and others [4]. Approximately $25 \%$ of the patients present with advanced disease at diagnosis, and up to one third of those with localized disease that undergo surgery with a curative intention will recur requiring systemic treatment [5].

A better understanding of the molecular biology of RCC has allowed remarkable progress in therapeutics in the last decade. This advance comes primarily from the description of the Von Hippel -Lindau (VHL) syndrome; a hereditary condition associated with a mutation in the 
homonymous tumor suppressor gene, in which around $60 \%$ of the patients develop clear cell RCC (ccRCC). In normal conditions the VHL product (VHLp) creates a complex that targets hypoxia inducible factors 1 and 2 (HIF 1-2) for ubiquitin-mediated degradation. In the absence of VHLp by either mutation or methylation of VHL gene, HIF accumulates leading to exaggerated transcription of multiple genes involved in cell proliferation and angiogenesis such as the platelet-derived growth factor (PDGF), vascular endothelial growth factor (VEGF) and transforming growth factor [6-9]. The VEGF binds its receptor (VEGFR) and promotes proliferation and migration of endothelial cells, increased vascular permeability and revascularization during tumor development [10-12]. Similarly, PDGF and its receptors (PDGFRA, PDGFRB) play a critical role in regulating angiogenesis through controlling functions during the mesenchymal cell development. Signalling through PDGF also promotes cell migration, survival and proliferation and indirectly regulates angiogenesis by inducing transcription and secretion of VEGF [13]. These knowledge and the observation that around $90 \%$ of sporadic ccRCC have abnormal function of VHL has led to an intense drug development in RCC targeting VEGF, PDGF or their cognate receptors. Bevacizumab, a humanized monoclonal antibody against VEGF, was the first agent in this class to demonstrate activity in advanced RCC [14]. Thereafter multiple antiangiogenics such as the tyrosine kinase inhibitors sunitinib, sorafenib, pazopanib or axitinib and mTOR inhibitors such as temsirolimus or everolimus, have shown remarkable activity in advanced RCC becoming standard of treatment in different settings [15]. More recently other therapeutic strategies such as targeting the program-death 1 (PD-1) receptor or the hepatocyte growth factor receptor (MET) have also succeeded [16, 17].

Although the availability of all these drugs has improved substantially the therapeutic results in RCC, approximately $40 \%$ of patients treated in first-line will not achieve an objective response and about $20-25 \%$ will present an early progression. Currently available prognostic systems fail to identify these patients and no adequate predictive factors of response have been validated in advanced RCC yet.

The variability in the genetic constitution of the individual in critical genes related to disease mechanisms or anti-cancer drug metabolism could explain this variable clinical course. Single nucleotides polymorphisms (SNPs) are the most common genetic variations in the DNA sequence, involve a single base and have a frequency of greater than $1 \%$ in at least one minor allele population [18]. Certain SNPs have already been identified as potential predictors of efficacy and/or toxicity in advanced RCC patients treated with tyrosine kinase inhibitors [19-26].

The present study aims to analyse the incidence of SNPs in genes related with angiogenesis or metabolism of antiangiogenics in patients with localized and advanced $\mathrm{RCC}$ and to test their potential as prognostic and/or predictive factors.

\section{RESULTS}

One hundred and two patients were initially included in the study, $65 \%$ were male and the median age was 62 years (range 29-83 years). Three patients were excluded from the final analysis due to incomplete clinical information available. The median of follow-up was 62 months. Table 1 shows clinical characteristics for localized (a) and metastatic (b) patients and the association of these characteristics with disease/progression free survival (DFS and PFS) and overall survival (OS) (c).

One triallelic SNP (rs2032582) was excluded from the analysis due to inconsistent results with the array utilized. The minor allele frequencies (MAF) of the others 62 polymorphisms genotyped (Table 2) were consistent with the data described elsewhere for European and Iberian population (1000 genomes, dbSNP database) and all SNPs were in Hardy-Weinberg equilibrium $(p>0.05)$. Table 2 shows the characteristics for the 62 polymorphisms genotyped and frequency in our tumor samples in localized and metastatic patients.

Patients were classified in two cohorts for analysis purposes: localized and metastatic. A number of SNPs showed either a protective or adverse effect (Table 3A). Thus, in patients with localized tumors, one polymorphism, rs2071559 in VEGFR2 gene was associated with a protective effect: the mean of patients with this SNP presented a DFS of 49 month vs. 19 months when the SNP was absent. Another two, rs2228230 and rs10013228 in two genes (PDGFRA and VEGFR2) were significantly associated with worse DFS in the multivariate analysis. Accordingly, the absence of rs2228230 associated with an increased DFS (43 months) compared with 25 months in those patients harbouring the SNP. For rs 10013228 the deleterious effect in DFS was even of a larger magnitude (62 months vs. 31 months). Additionally, rs10013228 was also significantly associated with a shorter OS (136 vs. 120 months). Other two SNPs (rs307826 and rs6877011) in VEGFR3 were also confirmed as predictors of shorter OS (127 vs. 96 months and 139 vs. 30 months, respectively).

In metastatic patients, two SNPs: rs9800958 (PRKAR1B) $(p=0.05)$ and rs2302273 (PDGFRB) $(p=0.05)$, showed a tendency towards a better OS in the multivariant analysis (Table 3B). In terms of activity, two SNPs correlated with better response rate (RR): rs2016110 (VEGFC) $(p=0.07)$ and rs594942 (VEGFB) $(p=0.03)$ and another two: rs699947and rs3025010 (VEGFA) $(p<0.005)$ associated with a worse RR (Table 3C). DFS and OS curves for statistically significant SNPs are illustrated in Figures 1 and 2. When analyzing the predictive role of clinical variables, in the localized disease cohort, TNM stage T1 or T2 associated with a better DFS $(p=0.001)$ and OS $(p=0.055)$. In metastatic patients, Fuhrman grade (1-2) $(p=0.027)$ correlated with better progression free survival (PFS) and normal hemoglobin $(p=0.036)$ and ECOG 0 were 
Table 1A: Clinical features of patients with localized disease. $N=$ number of patients, $\%=$ percentage of patients, Total $=$ total of patients

\begin{tabular}{|c|c|c|c|}
\hline Clinical feature & $N$ & $\%$ & Total \\
\hline \multicolumn{4}{|l|}{ Gender } \\
\hline Male & 45 & $62 \%$ & \multirow{2}{*}{73} \\
\hline Female & 28 & $38 \%$ & \\
\hline \multicolumn{4}{|l|}{ Age } \\
\hline$\geq 60$ & 45 & $62 \%$ & \multirow[t]{2}{*}{73} \\
\hline$<60$ & 28 & $38 \%$ & \\
\hline \multicolumn{4}{|l|}{ Diagnosis } \\
\hline Incidental & 36 & $49 \%$ & \multirow{5}{*}{73} \\
\hline Back Pain & 1 & $1 \%$ & \\
\hline Hematuria & 8 & $11 \%$ & \\
\hline Constitutional symptoms & 4 & $6 \%$ & \\
\hline Others & 24 & $33 \%$ & \\
\hline \multicolumn{4}{|l|}{ Nephrectomy } \\
\hline Yes & 73 & $100 \%$ & \multirow{2}{*}{73} \\
\hline No & - & - & \\
\hline Partial & 3 & $4 \%$ & \multirow{2}{*}{73} \\
\hline Complete & 70 & $96 \%$ & \\
\hline Open surgery & 64 & $88 \%$ & \multirow{2}{*}{73} \\
\hline Laparoscopy & 9 & $12 \%$ & \\
\hline \multicolumn{4}{|l|}{ Histology } \\
\hline Clear cell & 54 & $74 \%$ & \multirow{3}{*}{73} \\
\hline Papillary & 16 & $22 \%$ & \\
\hline Other & 3 & $4 \%$ & \\
\hline \multicolumn{4}{|l|}{ Furhman Grade } \\
\hline 1 & 24 & $36 \%$ & \multirow{4}{*}{$66^{*}$} \\
\hline 2 & 21 & $32 \%$ & \\
\hline 3 & 18 & $27 \%$ & \\
\hline 4 & 3 & $5 \%$ & \\
\hline \multicolumn{4}{|l|}{ Furhman Grade Groups } \\
\hline $1-2$ & 46 & $70 \%$ & \multirow{2}{*}{$66^{*}$} \\
\hline $3-4$ & 20 & $30 \%$ & \\
\hline \multicolumn{4}{|l|}{ Diagnosis TNM } \\
\hline $\mathrm{T} 1-\mathrm{T} 2$ & 54 & $74 \%$ & \multirow{2}{*}{73} \\
\hline $\mathrm{T} 3-\mathrm{T} 4$ & 19 & $26 \%$ & \\
\hline \multicolumn{4}{|l|}{ ECOG } \\
\hline 0 & 20 & $83 \%$ & \multirow{2}{*}{$24^{*}$} \\
\hline$>0$ & 4 & $17 \%$ & \\
\hline
\end{tabular}

* Only available data is presented. 
Table 1B: Clinical features of patients with metastatic disease. $N=$ number of patients, $\%=$ percentage of patients, Total $=$ total of patients

\begin{tabular}{|c|c|c|c|}
\hline Clinical feature & $N$ & $\%$ & Total \\
\hline \multicolumn{4}{|l|}{ Gender } \\
\hline Male & 35 & $70 \%$ & \multirow{2}{*}{50} \\
\hline Female & 15 & $30 \%$ & \\
\hline \multicolumn{4}{|l|}{ Age } \\
\hline$\geq 60$ & 22 & $44 \%$ & \multirow{2}{*}{50} \\
\hline$<60$ & 28 & $66 \%$ & \\
\hline \multicolumn{4}{|l|}{ Diagnosis } \\
\hline Incidental & 15 & $30 \%$ & \multirow{5}{*}{50} \\
\hline Back Pain & 2 & $4 \%$ & \\
\hline Hematuria & 8 & $16 \%$ & \\
\hline Constitutional symptoms & 6 & $12 \%$ & \\
\hline Others & 19 & $38 \%$ & \\
\hline \multicolumn{4}{|l|}{ Nephrectomy } \\
\hline Yes & 43 & $86 \%$ & \multirow{2}{*}{50} \\
\hline No & 7 & $14 \%$ & \\
\hline Partial & 1 & $2 \%$ & \multirow{2}{*}{43} \\
\hline Complete & 42 & $98 \%$ & \\
\hline Open surgery & 39 & $91 \%$ & \multirow{2}{*}{43} \\
\hline Laparoscopy & 4 & $9 \%$ & \\
\hline \multicolumn{4}{|l|}{ Histology } \\
\hline Clear cell & 41 & $82 \%$ & \multirow{3}{*}{50} \\
\hline Papillary & 5 & $10 \%$ & \\
\hline Other & 4 & $8 \%$ & \\
\hline \multicolumn{4}{|l|}{ Furhman Grade } \\
\hline 1 & 7 & $18 \%$ & \multirow{4}{*}{$38^{*}$} \\
\hline 2 & 12 & $32 \%$ & \\
\hline 3 & 13 & $34 \%$ & \\
\hline 4 & 6 & $16 \%$ & \\
\hline \multicolumn{4}{|l|}{ Furhman Grade Groups } \\
\hline $1-2$ & 19 & $50 \%$ & \multirow{2}{*}{$38^{*}$} \\
\hline $3-4$ & 19 & $50 \%$ & \\
\hline \multicolumn{4}{|l|}{ Diagnosis TNM } \\
\hline $\mathrm{T} 1-\mathrm{T} 2$ & 15 & $30 \%$ & \multirow{2}{*}{50} \\
\hline $\mathrm{T} 3-\mathrm{T} 4$ & 35 & $70 \%$ & \\
\hline \multicolumn{4}{|l|}{ ECOG } \\
\hline 0 & 33 & $66 \%$ & \multirow{2}{*}{50} \\
\hline$>0$ & 17 & $34 \%$ & \\
\hline \multicolumn{4}{|l|}{ Metastasis } \\
\hline Lung & 34 & $68 \%$ & \multirow{5}{*}{50} \\
\hline Liver & 7 & $14 \%$ & \\
\hline Nodes & 16 & $32 \%$ & \\
\hline Bones & 6 & $12 \%$ & \\
\hline Brain & 1 & $2 \%$ & \\
\hline
\end{tabular}


MSKCC prognosis (Karnofsky Hemoglobin, LDH, calcium)

\section{Karnofsky}

$\geq 80 \%$

$<80 \%$

45

$90 \%$

$10 \%$

Hemoglobin

$<$ LLN

22

$44 \%$

Normal

$56 \%$

LDH

$\geq 1.5 \mathrm{ULN}$

$<1.5 \mathrm{ULN}$

$4 \%$

$96 \%$

\section{Corrected calcium}

$\geq 10 \mathrm{mg} / \mathrm{dl}$

$<10 \mathrm{mg} / \mathrm{dl}$

$2 \%$

$98 \%$

Time nephrectomy-systemic treatment

$$
\begin{aligned}
& \geq 1 \text { year } \\
& <1 \text { year }
\end{aligned}
$$

$42 \%$

$58 \%$

\section{Prognosis Group}

Favorable

$24 \%$

Intermediate

Poor

\begin{tabular}{|c|c|c|}
\hline TKI & 43 & $86 \%$ \\
\hline Sunitinib & 33 & \\
\hline Pazopanib & 10 & \\
\hline mTOR & 7 & $14 \%$ \\
\hline Temsirolimus & 5 & \\
\hline Everolimus & 2 & \\
\hline
\end{tabular}

Systemic treatment

* Only available data is presented.

Table 1C: Clinical features of patients associated with Disease Free Survival (DFS) or Progression Free Survival (PFS)

\begin{tabular}{|c|c|c|c|c|}
\hline \multirow{2}{*}{$\begin{array}{l}\text { Patients } \\
\text { Clinical features }\end{array}$} & \multicolumn{2}{|c|}{ Localized disease $(p)$} & \multicolumn{2}{|c|}{ Metastatic disease $(p)$} \\
\hline & DFS & OS & PFS & OS \\
\hline Gender & 0.345 & 0.767 & 0.493 & 0.470 \\
\hline Age $(\geq 60$ vs $<60)$ & 0.440 & 0.570 & 0.108 & 0.773 \\
\hline Diagnosis (incidental vs others) & 0.499 & 0.832 & - & - \\
\hline Nephrectomy (yes/no) & \multicolumn{2}{|c|}{ NA } & 0.660 & 0.080 \\
\hline Partial/Complete & 0.230 & - & - & 0.395 \\
\hline Open surgery/ Laparoscopy & 0.900 & 0.426 & 0.563 & 0.140 \\
\hline Histology (clear cell vs papillary vs others) & 0.997 & 0.491 & 0.381 & 0.168 \\
\hline Furhman Grade (1-2 vs 3-4) & 0.185 & 0.328 & 0.027 & - \\
\hline TNM (T1-T2 vs T3-T4) & 0.001 & 0.055 & 0.170 & 0.474 \\
\hline $\operatorname{ECOG}(0 \mathrm{vs}>0)$ & - & 0.064 & 0.173 & 0.017 \\
\hline \multicolumn{5}{|l|}{ Metastasis } \\
\hline Lung & & & 0.179 & 0.118 \\
\hline Liver & & & - & 0.210 \\
\hline
\end{tabular}
and Overall Survival (OS) ( $p$ values $>0.999$ not shown) 


\begin{tabular}{lcc}
\multicolumn{1}{l}{ Nodes } & 0.731 & 0.357 \\
$\quad$ Bones & - & 0.083 \\
$\quad$ Brain & NA & - \\
Karnofsky $(\geq 80 \%$ vs $<80 \%)$ & & 0.152 \\
Hemoglobin $(<$ LLN vs normal) & 0.309 & 0.036 \\
LDH $(\geq 1.5$ ULN vs $<1.5$ ULN) & - & 0.542 \\
Corrected calcium $(\geq 10$ vs $<10$ mg/dl) & - & - \\
Time nephrectomy-systemic treatment $(\geq 1$ vs $<1$ year) & 0.027 & 0.020 \\
Prognosis Group (Favorable vs Intermediate/Poor) & 0.01 & 0.001 \\
Systemic treatment (TKI vs mTor) & - & 0.235 \\
\hline
\end{tabular}

NA: Not apply for patients with localized disease.

significant for a better OS. Intermediate or poor prognosis $(p \leq 0.01)$ and time between nephrectomy and systemic treatment $(>1$ year) $(p=0.020)$ were associated with both, shorter PFS and OS.

\section{DISCUSSION}

Despite major advances in the knowledge of the molecular basis and therapeutics of RCC, prognostic and predictive estimation remains largely based on clinical and blood test parameters. This is an exploratory pharmacogenetic study designed to identify SNPs that could contribute to select patients with better prognosis and /or higher chances of benefiting from systemic treatment. We studied 62 polymorphisms from 18 genes in 99 patients on the basis of allele frequency and functionality evidence. Our study showed that the presence of certain SPNs was statistically associated with the progression of the disease, the response to treatment and the overall survival in this RCC patient population.

In patients with localized disease, the SNPs that had clinical significance were those positioned in receptors of VEGF and PDGF such as VEGFR2, VEGFR3 or PDGFR. SNPs located in these genes could potentially influence the activation of their cognate signaling pathways, which is a well-established mechanism of RCC tumorigenesis. We found that patients wild type for rs 10013228 have a better DFS and OS. No studies in European populations or in RCC patients have been found in this regard. To our knowledge, the only reference in the literature of this SNP comes from a Chinese cohort of localized colorectal cancer patients where it had shown a protective effect [27]. Rs2071559 is a promoter SNP associated with VEGFR2 transcription activity [28]. In our study the AA genotype was associated with a protective effect increasing the DFS. These results are in concordance with data from other reported studies. In a recent metastatic RCC analysis [28], this polymorphism was shown to predict for sorafenib (an anti-VEGFR) efficacy. Promising results have been also described in metastatic colorectal cancer where this VEGFR2 polymorphism was significantly associated with increased PFS and OS in multivariate analysis in metastatic patients treated with first-line oxaliplatin-based chemotherapy regardless the KRAS mutational status [29]. Likewise a study in patients with localized colorectal cancer suggested a protective role for rs2071559, especially in patients that had received chemotherapy [27]. Data from other tumor types also pointed in a similar direction. An analysis in hepatocellular carcinoma patients treated with sorafenib showed that the presence of rs2071559 was a predictor of better outcomes [30]. SNPs in VEGFR3 were also associated with treatment outcomes. Thus, the absence of the SNPs rs307826 and rs6877011 were predictors of better outcome. This is consistent with other reports in RCC patients treated with the anti-VEGFR sunitinib where the presence of the genetic variant rs307826 or rs6877011 was associated with a shorter DFS [19] and OS [31].

Our study also found that SNPs in the PDGFRA gene such as rs2228230 significantly associated with worse prognosis. No previous reports exist about this SNP in RCC. Its presence has been reported in rare cancers such as extraintestinal stromal tumors and cervical adeno-squamous carcinoma, nevertheless its prognostic or predictive role remains largely unexplored $[32,33]$. In our series we could not confirm a variation in response to different PDGFR-inhibitors such as sunitinib or sorafenib based on the presence of this SNP. The limited sample size when stratifying by treatment arms could explain these results.

Three SNPs were found relevant at predicting survival in advanced RCC patients. One of them in the Interleukin 8 (IL8) gene (rs2227543) is a 3 prime UTR variant, and therefore variations in these regions could significantly impact in the metabolism of the protein. IL-8 is a pro-inflammatory chemokine that execute an angiogenic function, thus, variations on this gene could influence tumor cell growth and angiogenesis. Only one report has associated this SNP with cancer, suggesting 
Table 2: Characteristics for the 62 polymorphisms genotyped and frequency in our tumor samples in localized and metastatic patients

\begin{tabular}{|c|c|c|c|c|c|c|c|c|c|}
\hline & dbSNP & Gene & Chrom. & HGVS name & Location & $\begin{array}{l}\text { Type of SNP } \\
\text { variant }\end{array}$ & $\begin{array}{c}\text { Minor } \\
\text { allele }\end{array}$ & $N$ Localized & $\begin{array}{c}N \\
\text { Metastatic }\end{array}$ \\
\hline 1 & rs699947 & VEGFA & $6 \mathrm{p} 21.1$ & $6: \mathrm{g} .43736389 A>C$ & $6: 43736389$ & Upstream gene & $\mathrm{A}(46.7)$ & $43(58.9)$ & $16(61.5)$ \\
\hline 2 & rs 833061 & VEGFA & $6 \mathrm{p} 21.1$ & $6: \mathrm{g} .43737486 \mathrm{C}>\mathrm{T}$ & $6: 43737486$ & Upstream gene & $\mathrm{C}(47.2)$ & $41(56.2)$ & $16(61.5)$ \\
\hline 3 & rs3025010 & VEGFA & $6 \mathrm{p} 21.1$ & 6:g.43747577T $>C$ & $6: 43747577$ & $\begin{array}{l}\text { Non coding } \\
\text { transcript exon }\end{array}$ & C (36) & $36(49.3)$ & $17(65.4)$ \\
\hline 4 & rs3025033 & VEGFA & $6 \mathrm{p} 21.1$ & $6: \mathrm{g} .43751075 \mathrm{~A}>\mathrm{G}$ & $6: 43751075$ & $\begin{array}{l}\text { Non coding } \\
\text { transcript exon }\end{array}$ & G (15) & $22(30.1)$ & $8(30.8)$ \\
\hline 5 & rs2010963 & VEGFA & $6 \mathrm{p} 21.1$ & $6: \mathrm{g} .43738350 \mathrm{C}>\mathrm{G}$ & $6: 43738350$ & 5 prime UTR & $\mathrm{C}(33.6)$ & $37(50.7)$ & $11(42.3)$ \\
\hline 6 & rs 1570360 & VEGFA & $6 \mathrm{p} 21.1$ & 6:g.43737830A $>\mathrm{G}$ & $6: 43737830$ & Upstream gene & $\mathrm{A}(30)$ & $15(20.5)$ & $1(3.8)$ \\
\hline 7 & rs3025039 & VEGFA & $6 \mathrm{p} 21.1$ & 6:g.43752536C $>\mathrm{T}$ & $6: 43752536$ & 3 prime UTR & $\mathrm{T}(13)$ & $15(20.5)$ & $6(23.1)$ \\
\hline 8 & rs4930152 & VEGFB & $11 \mathrm{q} 13.1$ & $11: \mathrm{g} .64005412 \mathrm{G}>\mathrm{A}$ & $11: 64005412$ & Intron variant & $\mathrm{A}(31)$ & $37(50.7)$ & $69.2(18)$ \\
\hline 9 & rs594942 & VEGFB & 11q13.1 & 11:g.64006292T $>C$ & 11:64006292 & Upstream gene & $\mathrm{T}(30)$ & $45(61.6)$ & $14(53.8)$ \\
\hline 10 & rs2016110 & VEGFC & $4 \mathrm{q} 34.3$ & 4:g.177604081A>G & 4:177604081 & Intron & A (13) & $25(34.2)$ & $8(30.8)$ \\
\hline 11 & rs1485766 & VEGFC & $4 q 34.3$ & 4:g.177610884T $>\mathrm{G}$ & $4: 177610884$ & Intron & G (49) & $42(57.5)$ & $12(46.2)$ \\
\hline 12 & rs11947611 & VEGFC & $4 q 34.3$ & 4:g.177611397G $>$ A & $4: 177611397$ & Intron & $\mathrm{A}(46)$ & $32(43.8)$ & $10(38.5)$ \\
\hline 13 & rs2877967 & VEGFC & $4 q 34.3$ & 4:g.177707602C $>\mathrm{T}$ & $4: 177707602$ & Intron & C (14) & $17(23.3)$ & $4(15.4)$ \\
\hline 14 & rs4604006 & VEGFC & $4 \mathrm{q} 34.3$ & 4:g.177608775T $>C$ & $4: 177608775$ & Intron & $\mathrm{T}(27)$ & $24(32.9)$ & $12(46.2)$ \\
\hline 15 & rs2305948 & VEGFR2 & $4 \mathrm{q} 12$ & 4:g.55979558C $>\mathrm{T}$ & 4:55979558 & Missense & $\mathrm{T}(14)$ & $21(28.8)$ & $4(15.4)$ \\
\hline 16 & rs1870377 & VEGFR2 & $4 q 12$ & $4: \mathrm{g} .55972974 \mathrm{~T}>\mathrm{A}$ & 4:55972974 & Missense & $\mathrm{A}(25)$ & $21(28.8)$ & $6(23.1)$ \\
\hline 17 & rs 12505758 & VEGFR2 & $4 q 12$ & 4:g.55966898T $>C$ & 4:55966898 & Intron & $\mathrm{C}(12)$ & $26(19)$ & $19.2(5)$ \\
\hline 18 & rs 10013228 & VEGFR2 & $4 q 12$ & $4: g .55997340 \mathrm{~A}>\mathrm{G}$ & $4: 55997340$ & Intergenic & G (30) & $32(43.8)$ & $11(42.3)$ \\
\hline 19 & rs11941492 & VEGFR2 & $4 q 12$ & $4: \mathrm{g} .55978210 \mathrm{C}>\mathrm{T}$ & $4: 55978210$ & Intron & $\mathrm{T}(22)$ & $25(34.2)$ & $7(26.9)$ \\
\hline 20 & rs2071559 & VEGFR2 & $4 q 12$ & $4: g .55992366 \mathrm{~A}>\mathrm{G}$ & 4:55992366 & Upstream gene & $\mathrm{A}(47)$ & $50(68.5)$ & $16(61.5)$ \\
\hline 21 & rs1531290 & VEGFR2 & $4 q 12$ & $4: \mathrm{g} .55986562 \mathrm{G}>\mathrm{A}$ & $4: 55986562$ & Intron & $\mathrm{A}(47)$ & $41(56.2)$ & $15(57.7)$ \\
\hline 22 & rs6828477 & VEGFR2 & $4 q 12$ & 4:g.55966801C > T & 4:55966801 & Intron & C (43) & $18(24.7)$ & $10(38.5)$ \\
\hline 23 & rs 307826 & VEGFR3 & $5 \mathrm{q} 35.3$ & 5:g.180051003T $>C$ & $5: 180051003$ & Missense & $\mathrm{C}(12)$ & $9(12.3)$ & $5(19.2)$ \\
\hline 24 & rs 307821 & VEGFR3 & $5 \mathrm{q} 35.3$ & 5:g.180030313C $>$ A & $5: 180030313$ & Missense & $\mathrm{A}(11)$ & $8(11)$ & $1(3.8)$ \\
\hline 25 & rs6877011 & VEGFR3 & $5 \mathrm{q} 35.3$ & 5:g.180029471C $>\mathrm{G}$ & $5: 180029471$ & 3 prime UTR & G (6) & $6(8.2)$ & $5(19.2)$ \\
\hline 26 & rs 779805 & VHL & $3 \mathrm{p} 25.3$ & 3:g.10183337G $>A$ & $3: 10183337$ & 5 prime UTR & G (28) & $25(34.2)$ & $9(34.6)$ \\
\hline 27 & rs1642742 & VHL & $3 \mathrm{p} 25.3$ & 3:g.10191943G $>A$ & $3: 10191943$ & 3 prime UTR & G (29) & $28(38.4)$ & $15(57.7)$ \\
\hline 28 & rs2227543 & IL8 & $4 q 13.3$ & 4:g.74607910C $>\mathrm{T}$ & $4: 74607910$ & 3 prime UTR & $\mathrm{T}(42)$ & $37(50.7)$ & $14(53.8)$ \\
\hline 29 & rs 4073 & IL8 & $4 q 13.3$ & 4:g.74606024A>T & $4: 74606024$ & Upstream gene & $\mathrm{A}(47)$ & $30(41.1)$ & $11(42.3)$ \\
\hline 30 & rs1800795 & IL6 & $7 \mathrm{p} 15.3$ & $7: \mathrm{g} .22766645 \mathrm{C}>\mathrm{G}$ & $7: 22766645$ & Intron & C (35) & $36(49.3)$ & $17(65.4)$ \\
\hline 31 & rs1045642 & $\mathrm{ABCB} 1$ & $7 \mathrm{q} 21.12$ & $7: \mathrm{g} .87138645 \mathrm{~A}>\mathrm{T}$ & $7: 87138645$ & Synonymous & $\mathrm{A}(46)$ & $46(63)$ & $20(76.9)$ \\
\hline 32 & rs1128503 & ABCB1 & $7 \mathrm{q} 21.12$ & $7: g .87179601 \mathrm{~A}>\mathrm{G}$ & $7: 87179601$ & Synonymous & A (38) & $51(69.9)$ & $18(69.2)$ \\
\hline 33 & rs2231142 & ABCG2 & $4 \mathrm{q} 22.1$ & $4: \mathrm{g} .89052323 \mathrm{G}>\mathrm{T}$ & $4: 89052323$ & Missense & $\mathrm{T}(7)$ & $5(6.8)$ & $3(11.5)$ \\
\hline 34 & rs3814055 & NR1I2 & $3 q 13.33$ & 3:g.119500035C $>\mathrm{T}$ & $3: 119500035$ & 5 prime UTR & $\mathrm{T}(40)$ & $47(64.4)$ & $15(57.7)$ \\
\hline 35 & rs2276707 & NR1I2 & $3 q 13.33$ & 3:g.119534153C $>\mathrm{T}$ & $3: 119534153$ & Intron & $\mathrm{T}(18)$ & $21(28.8)$ & $13(50)$ \\
\hline 36 & rs2307424 & NR1I3 & $1 \mathrm{q} 23.3$ & 1:g.161202605G $>$ A & $1: 161202605$ & Synonymous & $\mathrm{A}(35)$ & $32(43.8)$ & $16(61.5)$ \\
\hline 37 & rs4073054 & NR1I3 & $1 \mathrm{q} 23.3$ & 1:g.161200487C $>$ A & $1: 161200487$ & 3 prime UTR & C (34) & $34(46.6)$ & $11(42.3)$ \\
\hline 38 & rs 2740574 & CYP3A4 & $7 \mathrm{q} 22.1$ & 7:g.99382096C $>\mathrm{T}$ & 7:99382096 & Upstream gene & $\mathrm{C}(3)$ & $3(4.1)$ & $1(3.8)$ \\
\hline 39 & rs 776746 & CYP3A5 & $7 \mathrm{q} 22.1$ & 7:g.99270539C $>\mathrm{T}$ & 7:99270539 & Splice acceptor & $\mathrm{T}(7)$ & $9(12.3)$ & $4(15.4)$ \\
\hline 40 & rs9800958 & PRKAR1B & $7 \mathrm{p} 22.3$ & 7:g.668723A>G & $7: 668723$ & Intron & $\mathrm{A}(27)$ & $59(80.8)$ & $20(76.9)$ \\
\hline 41 & rs9768991 & PRKAR1B & $7 \mathrm{p} 22.3$ & 7:g.671687T $>C$ & $7: 671687$ & Intron & $\mathrm{T}(27)$ & $25(34.2)$ & $9(34.6)$ \\
\hline 42 & rs9611117 & PDGFB & $22 q 13.1$ & $22:$ g.39624105T $>$ G & $22: 39624105$ & Intron & G (45) & $51(69.9)$ & $14(53.8)$ \\
\hline 43 & rs 879180 & PDGFB & $22 \mathrm{q} 13.1$ & 22:g.39631547T $>$ C & $22: 39631547$ & Intron & $\mathrm{T}(26)$ & $26(35.6)$ & $11(42.3)$ \\
\hline 44 & rs35597368 & PDGFRA & $4 q 12$ & $4: g .55139771 \mathrm{~T}>\mathrm{C}$ & 4:55139771 & Missense & $\mathrm{C}(8)$ & $8(11)$ & $7(26.9)$ \\
\hline 45 & rs2114039 & PDGFRA & $4 q 12$ & $4: \mathrm{g} .55092626 \mathrm{~T}>\mathrm{C}$ & $4: 55092626$ & Intron & C (30) & $28(38.4)$ & $9(34.6)$ \\
\hline
\end{tabular}




\begin{tabular}{|c|c|c|c|c|c|c|c|c|c|}
\hline 46 & rs6554162 & PDGFRA & $4 q 12$ & 4:g.55093955G>A & $4: 55093955$ & Intron & $\mathrm{A}(30)$ & $31(42.5)$ & $11(42.3)$ \\
\hline 47 & rs1800812 & PDGFRA & $4 q 12$ & 4:g.55094629G $>\mathrm{T}$ & 4:55094629 & Intron & $\mathrm{T}(20)$ & $20(27.4)$ & $7(26.9)$ \\
\hline 48 & rs4358459 & PDGFRA & $4 q 12$ & 4:g.55133726T $>\mathrm{G}$ & $4: 55133726$ & Synonymous & $\mathrm{G}(10)$ & $9(12.3)$ & $6(23.1)$ \\
\hline 49 & rs 2228230 & PDGFRA & $4 q 12$ & 4:g.55152040C $>\mathrm{T}$ & $4: 55152040$ & Synonymous & $\mathrm{T}(13)$ & $12(16.4)$ & $4(15.4)$ \\
\hline 50 & rs17739921 & PDGFRA & $4 \mathrm{q} 12$ & 4:g.55164866A $>C$ & $4: 55164866$ & $\begin{array}{l}\text { Downstream } \\
\text { gene }\end{array}$ & $\mathrm{C}(47)$ & $51(69.9)$ & $15(57.7)$ \\
\hline 51 & rs246395 & PDGFRB & $5 \mathrm{q} 32$ & 5:g.149499672T $>C$ & 5:149499672 & Synonymous & $\mathrm{C}(27)$ & $44(60.3)$ & $22(84.6)$ \\
\hline 52 & rs246394 & PDGFRB & $5 \mathrm{q} 32$ & 5:g.149498151G $>$ A & 5:149498151 & Intron & A (25) & $35(47.9)$ & $10(38.5)$ \\
\hline 53 & rs3816018 & PDGFRB & $5 \mathrm{q} 32$ & 5:g.149508475C $>$ T & $5: 149508475$ & Intron & C (44) & $39(53.4)$ & $15(57.7)$ \\
\hline 54 & rs 17708574 & PDGFRB & $5 \mathrm{q} 32$ & 5:g.149521238G $>$ A & 5:149521238 & Intron & A (16) & $13(17.8)$ & $9(34.6)$ \\
\hline 55 & rs2302273 & PDGFRB & $5 \mathrm{q} 32$ & 5:g.149535255G $>$ A & $5: 149535255$ & 5 prime UTR & A (24) & $33(45.2)$ & $6(23.1)$ \\
\hline 56 & rs3828610 & PDGFRB & $5 \mathrm{q} 32$ & 5:g.149535625A $>C$ & $5: 149535625$ & Upstream gene & $\mathrm{C}(41)$ & $39(53.4)$ & $10(38.5)$ \\
\hline 57 & rs 2304060 & PDGFRB & $5 \mathrm{q} 32$ & 5:g.149501751A $>C$ & $5: 149501751$ & $\begin{array}{l}\text { Non coding } \\
\text { transcript exon }\end{array}$ & $\mathrm{C}(43)$ & $47(64.4)$ & $17(65.4)$ \\
\hline 58 & rs 17656204 & PDGFRB & $5 \mathrm{q} 32$ & 5:g.149501803C $>$ T & $5: 149501803$ & Intron & $\mathrm{T}(26)$ & $38(52.1)$ & $13(50)$ \\
\hline 59 & rs 11748255 & PDGFRB & $5 \mathrm{q} 32$ & 5:g.149512042G $>A$ & $5: 149512042$ & Intron & A (48) & $43(58.9)$ & $18(69.2)$ \\
\hline 60 & rs11740355 & PDGFRB & $5 \mathrm{q} 32$ & 5:g.149513626T $>\mathrm{G}$ & 5:149513626 & $\begin{array}{l}\text { Non coding } \\
\text { transcript exon }\end{array}$ & G (8) & $6(8.2)$ & $2(7.7)$ \\
\hline 61 & rs3776081 & PDGFRB & $5 \mathrm{q} 32$ & 5:g.149532107T $>C$ & 5:149532107 & Intron & $\mathrm{C}(37)$ & $40(54.8)$ & $14(53.8)$ \\
\hline 62 & rs4324662 & PDGFRB & $5 \mathrm{q} 32$ & 5:g.149531111C > T & $5: 149531111$ & Intron & $\mathrm{T}(24)$ & $31(42.5)$ & $8(30.8)$ \\
\hline
\end{tabular}

Chrom: Chromosome, Minor allele frequency for European or Iberian population (\%). $N$ : number of patients with the minor allele frequency (\%).

Upstream gene: the sequence variant is located in the $5^{\prime}$ position of the gene.

Downstream gene: the sequence variant is located in the $3^{\prime}$ position of the gene.

a potential role of genetic variations in IL genes as predictors of shorter DFS and OS in colorectal tumors. [34]. Likewise in our series, the presence of this genetic variant was associated with shorter OS.

The other two SNPs relevant in the advanced cohort (rs9800958 and rs2302273) are located in PRKAR1B, an oncogene related with cell growth and PDGFRB respectively. Both demonstrated a protective effect in our series with longer OS for the patients that harbour these variants. Rs9800958 is an intron variant of PRKAR1B and rs 2302273 is located in the 5 prime UTR variant of PDGFRB and therefore could affect the gene product by altering the binding of the transcription factor [35]. However, no data about the precise role of these SNPs in cancer has been communicated yet.

When looking at prediction of response SNPs in the VEGFA gene resulted of interest. The polymorphism rs699947 predicted worse prognosis in our analysis. This variant has been evaluated in metastatic RCC by other groups with contradictory results. In some series appears as a positive prognostic factor $[28,36,37]$ while others deny its prognostic or predictive value $[19,38]$. In the same gene, the presence of rs3025010 in our series was associated to worse prognosis. There are only two oncology reports about this SNP, one in non-small cell lung cancer [39] and other in hepatocellular carcinoma
[40] but neither of them established any correlation between the SNP and the response rate.

On the other hand, the presence of rs594942 in VEGFB has been associated with better response in our series. We have found only one citation of this polymorphism in metastatic colorectal cancer but without significance in the study [41].

All these results show the variability on the interpretation of polymorphisms depending on the type of cancer or the populations where they are evaluated. Nevertheless, the present exploratory study identified a set of SNPs that could improve prognostic and predictive estimation in RCC patients. Yet, the study might have a number of limitations that need to be taken into account. First the treatment varied across patients, although the majority $(86 \%)$ received tyrosine kinase inhibitors targeting VEGFR/PDGR. This fact could compromise the real predictive value of these genetic variants. Another limitation of the study is the multiple testing. In a relatively small cohort of patients, multiple SNPs (variables) are evaluated. Therefore, these results need to be cautiously interpreted and require further validation in larger series. Yet, the data here presented are hypothesis generating and could eventually help in optimizing patient selection in cancer therapeutics and improve prognostic estimation through genetic characterization. 
Table 3A: Most representative SNPs in patients with localized disease

\begin{tabular}{|c|c|c|c|c|c|}
\hline \multirow{2}{*}{ dbSNP } & \multirow{2}{*}{ Gene } & \multicolumn{4}{|c|}{ DFS [Months (m)] } \\
\hline & & SNP present & $\mathrm{UV}(p)$ & $\operatorname{MV}(p)$ & HR \\
\hline rs2071559 & VEGFR2 & 49 vs $19 \mathrm{~m}$ & 0.003 & 0.01 & 0.2 \\
\hline rs10013228 & VEGFR2 & $31 \mathrm{vs} 62 \mathrm{~m}$ & 0.07 & 0.03 & 4.6 \\
\hline rs 1870377 & VEGFR2 & 23 vs $51 \mathrm{~m}$ & 0.03 & 0.08 & 3.5 \\
\hline rs 2228230 & PDGFRA & $25 \mathrm{vs} 43 \mathrm{~m}$ & 0.21 & 0.01 & 21 \\
\hline \multirow{2}{*}{ dbSNP } & \multirow{2}{*}{ Gene } & \multicolumn{4}{|c|}{ OS [Months (m)] } \\
\hline & & SNP present & $\mathbf{U V}(p)$ & $\operatorname{MV}(p)$ & HR \\
\hline rs10013228 & VEGFR2 & 120 vs $136 \mathrm{~m}$ & 0.04 & 0.01 & 5.5 \\
\hline rs2305948 & VEGFR2 & 103 vs $138 \mathrm{~m}$ & 0.04 & 0.06 & 2.9 \\
\hline rs307826 & VEGFR3 & 96 vs 127 m & 0.10 & 0.03 & 3.6 \\
\hline rs6877011 & VEGFR3 & 30 vs 139 m & 0.001 & 0.003 & 5.5 \\
\hline
\end{tabular}

DFS: disease free survival, OS: overall survival, UV: univariant analysis, MV: multivariant analysis, HR: hazard ratio.

Table 3B: Most representative SNPs in patients with metastatic disease

\begin{tabular}{lccccc}
\hline \multirow{2}{*}{ dbSNP } & \multirow{2}{*}{ Gene } & \multicolumn{4}{c}{ OS [Months $(\mathbf{m})]$} \\
\cline { 2 - 5 } & & SNP present & UV $(\boldsymbol{p})$ & MV $(\boldsymbol{p})$ & HR \\
\hline rs9800958 & PRKAR1B & 32 vs 14 m & $\mathbf{0 . 0 3}$ & 0.05 & 0.3 \\
rs2302273 & PDGFRB & 42 vs 19 m & $\mathbf{0 . 0 1 4}$ & 0.05 & 0.1 \\
\hline
\end{tabular}

OS: overall survival, UV: univariant analysis, MV: multivariant analysis, HR: hazard ratio.

Table 3C: Most representative SNPs in patients with metastatic disease

\begin{tabular}{lllccccc}
\hline \multirow{2}{*}{ dbSNP } & \multirow{2}{*}{ Gene } & \multirow{2}{*}{ Result SNP present } & \multicolumn{2}{c}{ RR } & Total & \multicolumn{2}{c}{$(\boldsymbol{p})$} \\
\cline { 4 - 5 } \cline { 6 - 8 } & & & Responder $(\boldsymbol{n})$ & No-responder $(\boldsymbol{n})$ & $(\boldsymbol{n})$ & UV & MV \\
\hline rs2016110 & VEGFC & Better prognosis & 19 & 4 & 23 & $\mathbf{0 . 0 0 9}$ & 0.07 \\
rs594942 & VEGFB & Better prognosis & 16 & 4 & 20 & $\mathbf{0 . 0 2 5}$ & $\mathbf{0 . 0 3}$ \\
rs699947 & VEGFA & Worse prognosis & 8 & 23 & 31 & $\mathbf{0 . 0 1}$ & $\mathbf{0 . 0 0 4}$ \\
rs3025010 & VEGFA & Worse prognosis & 7 & 23 & 30 & $\mathbf{0 . 0 0 9}$ & $\mathbf{0 . 0 0 2}$ \\
\hline
\end{tabular}

RR: response rate, UV: univariant analysis, MV: multivariant analysis. (n): number of patients.

\section{MATERIALS AND METHODS}

\section{Selection and characteristics of patients}

Patients with localized and advanced RCC treated in the University Hospital "Virgen del Rocío" in the period 2000-2013 were included in the study. Paraffin embedded tumor samples were collected and patients were divided in two cohorts: those with localized disease and those with advanced RCC. The study protocol was approved by the Ethic Committee of Biomedical Investigation of Andalucía and conducted according to the principles of the Declaration of Helsinki.

The following inclusion criteria were considered: histologically confirmed diagnosis of primary RCC, complete clinical information and adequate tissue available $(60 \%-75 \%)$. As clinical data the following were included: sex, age, date of diagnosis, TNM stage, histological type, tumor differentiation (Furhman grade), surgical treatment (partial or complete nephrectomy), systemic treatment (tyrosine kinase inhibitor (TKI) or mammalian target of rapamycin (mTOR) inhibitor, grade 3 or 4 toxicities, date of last visit or death and cause of death. All patients were treated following clinical guidelines and scientific evidence. Objective response was classified according to RECIST 1.1 as complete response (CR), partial response $(\mathrm{PR})$, stable disease (SD), or progression of disease (PD).

\section{Selection of SNPs involved in angiogenesis and/ or metabolism of antiangiogenic drugs}

Sixty-four SNPs in 18 genes involved in angiogenesis and the mechanism of action of the drugs utilized in RCC therapeutics were selected (VEGFA, VEGFB, VEGFC, VEGFR2, VEGFR3, PRKAR1B, PDGFB, PDGFRA, PDGFRB, ABCB1, ABCG2, NR1/2, 
NR1/3, CYP3A4, CYP3A5, VHL, IL-8, IL-6) (Table 4). The selection of the SNPs to be analyzed was not systematic. Given the particular biology of RCC and the drugs utilized for treatment of this cancer we first selected genes involved in angiogenesis and also those related to the mechanism of action of tyrosine kinase inhibitors targeting VEGFR/PDGFR. Additionally we took into consideration previous studies, allele frequency in European and Iberian population (reference 100 Genomes Project), Hardy-Weinberg Equilibrium (Genotype frequencies are determined by allele frequencies at that locus) and linkage disequilibrium between SNPs determined by Haploview v4.2 software. This can be perceived as a limitation of the study [42]. Indeterminate results were coded as missing values for statistical analysis.

\section{DNA isolation and quantification}

Paraffin embedded samples from patients with RCC were obtained from surgical specimens from nephrectomy. For each sample of $10 \mu \mathrm{m}$, paraffin was removed and DNA was isolated with DNA kit QiAGEN protocol. DNA concentration was determined by Nanodrop (Thermo Scientific, DE, USA).

\section{Amplification of the samples and TaqMan SNP assays}

DNA was amplified, mixing $20 \mathrm{ng} / \mu \mathrm{l}$ of each DNA with the PreAmp Master Mix and PreAmp Pool (Life Technologies, Madrid, Spain) in 96-plate wells. This plate was sealed with MicroAmp clear adhesive film, centrifuged $30 \mathrm{~s}$ and put into GeneAmp PCR System 9700 that is specifically designed for the amplification of nucleic acids using the Polymerase Chain Reaction (PCR) process. The PCR conditions were: hold $95^{\circ} \mathrm{C}, 10 \mathrm{~min}$; denature $95^{\circ} \mathrm{C}, 15 \mathrm{sec}, 16$ cycles and anneal/extend $60^{\circ} \mathrm{C}$, $4 \mathrm{~min}, 16$ cycles. Afterwards, each sample was diluted (1/20) with buffer TE (Tris-EDTA). The plate could be used immediately or kept at $-20^{\circ} \mathrm{C}$ until next day. Samples were transferred duplicated into microArrays by a robotic axis. The result were obtained and interpreted by the TaqMan Genotyper Software (Life Technologies).
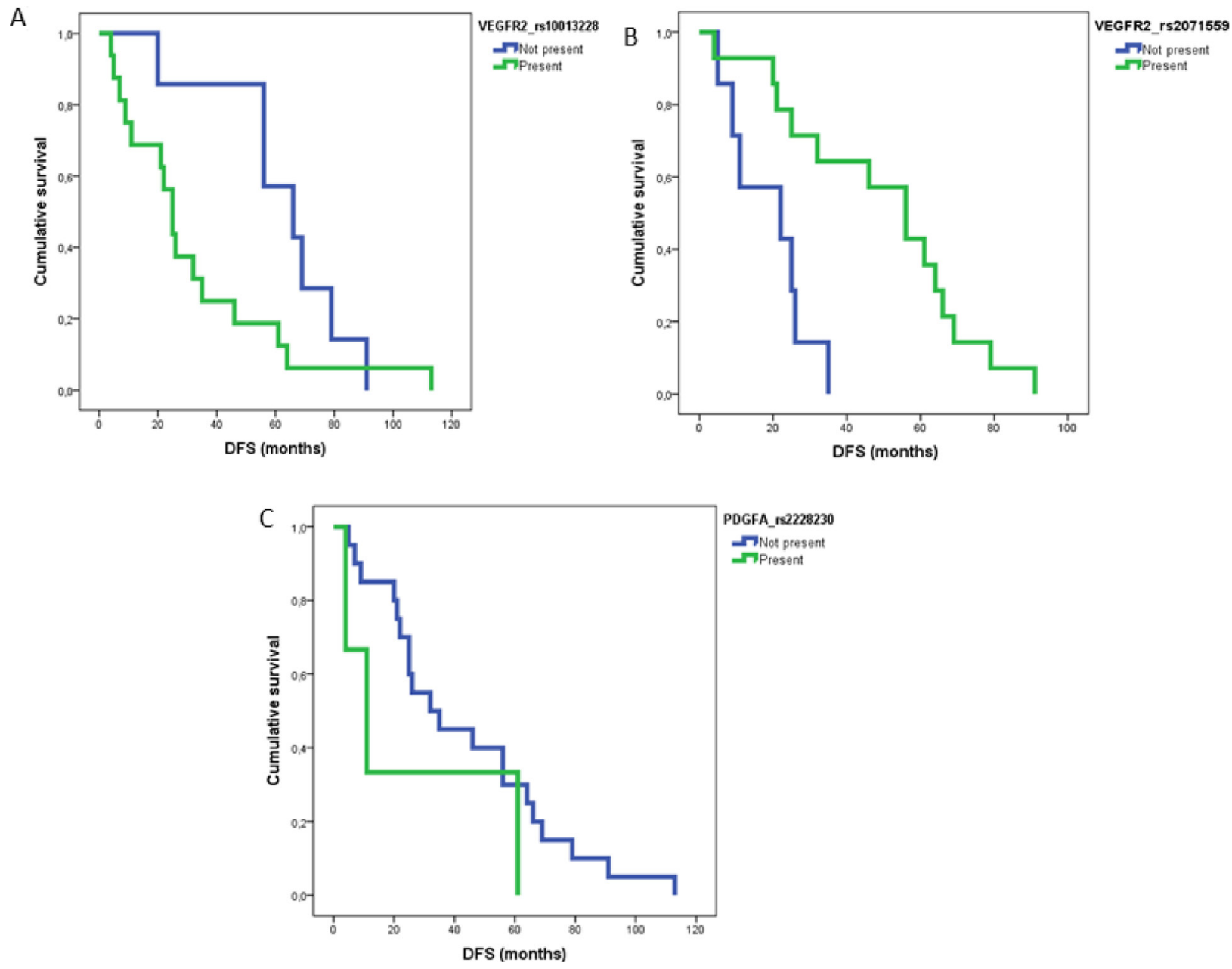

Figure 1: DFS curves for statistically significant SNPs in MV analysis for patients with localized disease. (A) rs10013228 ( $p=0.03)$; (B) $\operatorname{rs} 2071559(p=0.01)$ and (C) $\operatorname{rs} 2228230(p=0.01)$. 


\section{Statistical analysis}

The primary objective in the localized tumors cohort was to correlate the presence of SNPs with a worse DFS and OS. DFS was defined as the time between the diagnosis and the date of a radiological progression or death and OS as the time between the diagnosis and the date of death or last date of follow-up.

In the metastatic patients cohort overall RR, PFS and OS were analyzed and correlated with the presence SNPs. We considered overall RR as the percentage of CR and PR. The PFS was defined as the interval between the first day on systemic treatment and the date of radiological PD or death. Overall survival was defined as the time between the first day on treatment and the date of death or last date of follow-up.

Descriptive statistics were used to define the most relevant clinical features. The chi-squared test or Fisher's exact test were used in order to know the most relevant clinical variables to be included in the multivariate analysis. For this purpose, the DFS, PFS and OS parameters and RR variables with $p<$ 0.25 or those considered clinically relevant based on the previous literature on RCC were selected. These characteristics were: for patients with localized disease: type of nephrectomy (partial/complete), Furhman Grade (3-4), TNM stage and for patients with metastatic disease: Furhman Grade (3-4), TNM stage prognosis group (favorable vs intermediate/poor), metastasis lung and/or bones, Karnofsky, hemoglobin, time between nephrectomy and systemic treatment. ECOG was not included because the low number of patients in localized disease. All SNPs were tested in a univariant analysis for association with DFS, PFS and OS using KaplanMeier statistics and in a multivariate analysis using Cox proportional hazards to know the association between the presence of each SNPs and survival adjusting for potential confounding factors. Patients who had not progressed at database closure were censored at last follow-up. Also a chi-squared and a logistic regression were used to compare the presence of the SNPs and worse RR and the association of grade 3-4 toxicity with the presence of certain SNPs. $P<0.05$ was considered significant. All analyses were performed using the Statistical Package for the Social Sciences software (SPSS 20.0 for Windows; SPSS Inc, Chicago, IL).
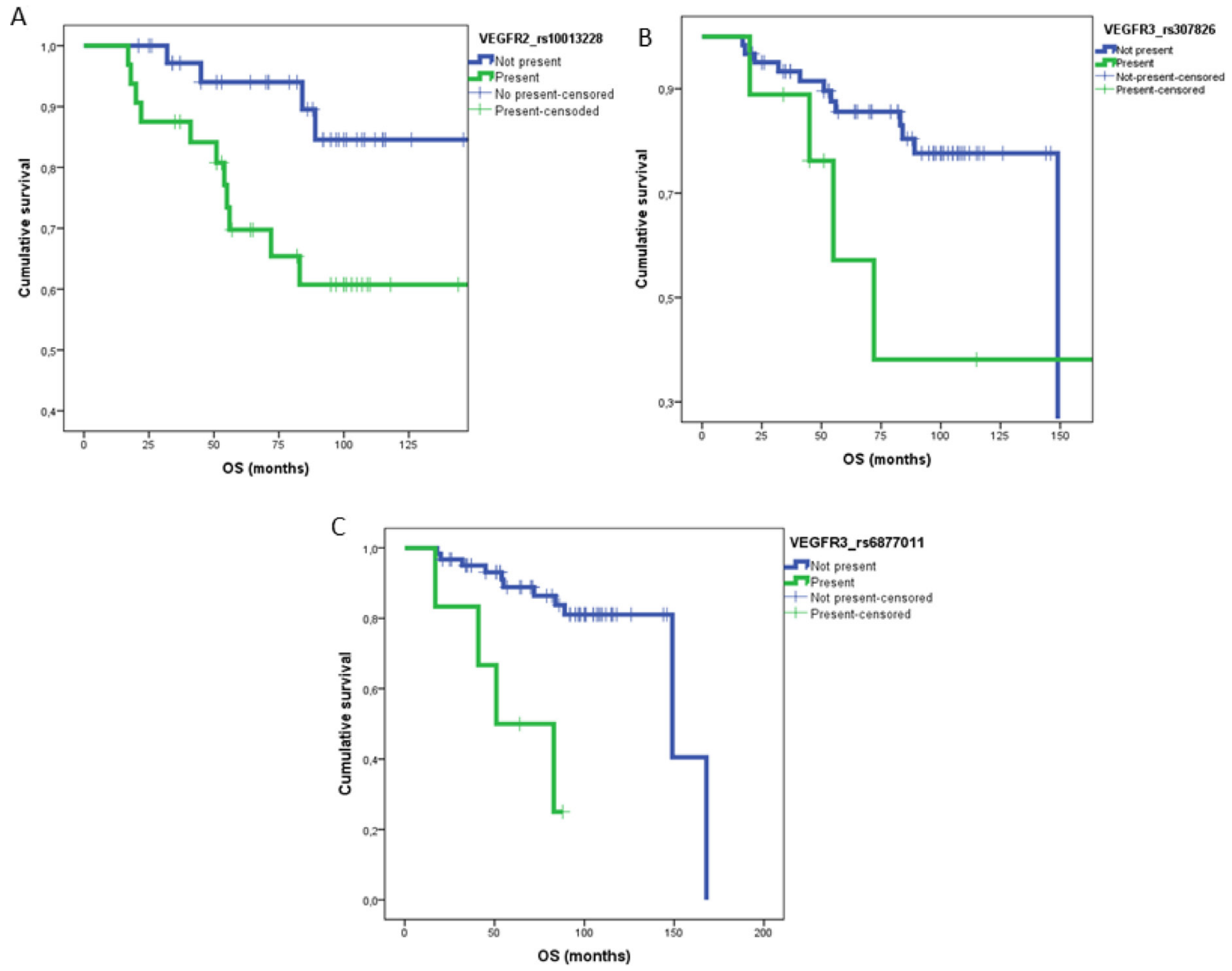

Figure 2: OS curves for statistically significant SNPs in MV analysis for patients with localized disease. (A) rs $10013228(p=0.01)$; (B) $\operatorname{rs} 307826(p=0.03)$ and $(\mathbf{C}) \operatorname{rs} 6877011(p=0.003)$. 
Table 4: SNPs in genes related with angiogenesis or metabolism of antiangiogenics in $\mathrm{RCC}$

\begin{tabular}{|c|c|c|c|c|c|c|c|c|}
\hline \multirow{2}{*}{$\begin{array}{l}\text { GENE } \\
\text { VEGFA }\end{array}$} & \multicolumn{8}{|c|}{ SNP } \\
\hline & rs699947 & rs833061 & rs3025010 & rs 3025033 & rs2010963 & rs 1570360 & rs3025039 & \\
\hline VEGFB & rs4930152 & rs594942 & & & & & & \\
\hline VEGFC & rs2016110 & rs 1485766 & rs11947611 & rs2877967 & rs4604006 & & & \\
\hline VEGFR2 & rs2305948 & rs 1870377 & rs 12505758 & rs 10013228 & rs11941492 & rs2071559 & rs1531290 & rs6828477 \\
\hline VEGFR3 & rs307826 & rs307821 & rs6877011 & & & & & \\
\hline PRKAR1B & rs9800958 & rs9768991 & & & & & & \\
\hline PDGFB & rs9611117 & rs879180 & & & & & & \\
\hline PDGFRA & rs35597368 & rs2114039 & rs6554162 & rs 1800812 & rs4358459 & rs 2228230 & rs17739921 & \\
\hline PDCEPP & rs 246395 & rs246394 & rs3816018 & rs 17708574 & rs 2302273 & rs3828610 & rs2304060 & rs17656204 \\
\hline P & rs 11748255 & rs11740355 & rs3776081 & rs4324662 & & & & \\
\hline ABCB1 & rs 1045642 & rs 1128503 & rs2032582 & & & & & \\
\hline ABCG2 & rs2231142 & & & & & & & \\
\hline NR1/2 & rs3814055 & rs2276707 & & & & & & \\
\hline NR1/3 & rs2307424 & rs4073054 & & & & & & \\
\hline CYP3A4 & rs2740574 & & & & & & & \\
\hline CYP3A5 & rs 776746 & & & & & & & \\
\hline VHL & rs 779805 & rs 1642742 & & & & & & \\
\hline IL-8 & rs 2227543 & rs 4073 & & & & & & \\
\hline IL-6 & rs1800795 & & & & & & & \\
\hline
\end{tabular}

\section{Abbreviations}

RCC, Renal Cell Cancer; SNP, Single Nucleotide Polymorphism; OS, Overall Survival; DFS, Disease Free Survival; PFS, Progression Free Survival; RR, Response Rate; ccRCC, clear cell Renal Cell Cancer; VHL, Von Hippel -Lindau; VHLp, Von Hippel -Lindau product; HIF, Hypoxia Inducible Factors; PDGF, platelet-derived growth factor; VEGF, vascular endothelial growth factor; PD-1, program-death 1; MET, hepatocyte growth factor receptor; MAF, minor allele frequencies; IL8, Interleukin 8; TKI, tyrosine kinase inhibitor; mTOR, mammalian target of rapamycin; $\mathrm{CR}$, complete response; $\mathrm{PR}$, partial response; $\mathrm{SD}$, stable disease; $\mathrm{PD}$, progression of disease; LD, linkage disequilibrium.

\section{Author contributions}

Conceptualization, I.D. and C.G.; Methodology, C.G., M.E. and A.S.; Formal Analysis, I.D., C.G. and M.E.; Samples Acquisition, I.O. and R.M.; Writing-Original Draft, I.D., C.G. and M.E.; Writing-Review \& Editing, I.D., C.G. and S.M.P.; Supervision, I. D., C.G. and S.M.P.; Funding Acquisition, I.D.

\section{ACKNOWLEDGMENTS}

The authors thank the donors and the HUVR-IBiS Biobank (Andalusian Public Health System Biobank and
ISCIII-Red de Biobancos PT13/0010/0056) for the human specimens used in this study.

\section{CONFLICTS OF INTEREST}

No potential conflicts of interest were disclosed by the authors.

\section{FUNDING}

This work was supported by a grant of the Andalusian Government through the program "Convocatoria Consejería de Salud y Bienestar Social 2012”. Project number PI-0427-2012.

\section{REFERENCES}

1. Ferlay J, Soerjomataram I, Ervik M, Dikshit R, Eser S, Mathers C, Rebelo M, Parkin DM, Forman D, Bray F. GLOBOCAN 2012 v1.0, Cancer Incidence and Mortality Worldwide: IARC CancerBase No. 11. Lyon, France: International Agency for Research on Cancer; 2013. Available from: http://globocan.iarc.fr, accessed on 12/05/2017.

2. Chow WH, Devesa SS. Contemporary epidemiology of renal cell cancer. Cancer J. 2008; 14:288-301. https://doi. org/10.1097/PPO.0b013e3181867628. 
3. Bellmunt J, Puente J, Garcia de Muro J, Lainez N, Rodriguez C, Duran I, Spanish Society for Medical Oncology. SEOM clinical guidelines for the treatment of renal cell carcinoma. Clin Transl Oncol. 2014; 16:1043-50. https://doi.org/10.1007/s12094-014-1219-1.

4. Eble J, Sauter G, Epstein J, Sesterhenn IA. Pathology and Genetics of Tumors of the Urinary System and Male Genital Organs. Ed. W.H.O.Classification of Tumours. 2004, IARC. Press: Lyon.

5. Cohen HT, McGovern FJ. Renal-cell carcinoma. N Engl J Med. 2005; 353:2477-90. https://doi.org/10.1056/ NEJMra043172.

6. Pavlovich CP, Schmidt LS. Searching for the hereditary causes of renal-cell carcinoma. Nat Rev Cancer. 2004; 4:381-93. https://doi.org/10.1038/nrc1364.

7. Latif F, Tory K, Gnarra J, Yao M, Duh FM, Orcutt ML, Stackhouse T, Kuzmin I, Modi W, Geil L. Identification of the von Hippel-Lindau disease tumor suppressor gene. Science. 1993; 260:1317-20.

8. Gnarra JR, Tory K, Weng Y, Schmidt L, Wei MH, Li H, Latif F, Liu S, Chen F, Duh FM, Lubensky I, Duan DR, Florence C, et al. Mutations of the VHL tumour suppressor gene in renal carcinoma. Nat Genet. 1994; 7:85-90. https:// doi.org/10.1038/ng0594-85.

9. Nickerson ML, Jaeger E, Shi Y, Durocher JA, Mahurkar S, Zaridze D, Matveev V, Janout V, Kollarova H, Bencko V, Navratilova M, Szeszenia-Dabrowska N, Mates D, et al. Improved identification of von Hippel-Lindau gene alterations in clear cell renal tumors. Clin Cancer Res. 2008; 14:4726-34. https://doi.org/10.1158/1078-0432.CCR-07-4921.

10. Carmeliet P, Jain RK. Angiogenesis in cancer and other diseases. Nature. 2000; 407:249-57. https://doi. org/10.1038/35025220.

11. Sakurai T, Kudo M. Signaling pathways governing tumor angiogenesis. Oncology. 2011; 81:24-9. https://doi. org/10.1159/000333256.

12. Neufeld G, Cohen T, Gengrinovitch S, Poltorak Z. Vascular endothelial growth factor (VEGF) and its receptors. FASEB J. 1999; 13:9-22.

13. Heidaran MA, Pierce JH, Yu JC, Lombardi D, Artrip JE, Fleming TP, Thomason A, Aaronson SA. Role of alpha beta receptor heterodimer formation in beta platelet-derived growth factor (PDGF) receptor activation by PDGF-AB. J Biol Chem. 1991; 266:20232-7.

14. Yang JC, Haworth L, Sherry RM, Hwu P, Schwartzentruber DJ, Topalian SL, Steinberg SM, Chen HX, Rosenberg SA. A randomized trial of bevacizumab, an anti-vascular endothelial growth factor antibody, for metastatic renal cancer. N Engl J Med. 2003; 349:427-34. https://doi. org/10.1056/NEJMoa021491.

15. Fisher R, Gore M, Larkin J. Current and future systemic treatments for renal cell carcinoma. Semin Cancer Biol. 2013; 23:38-45. https://doi.org/10.1016/j.semcancer.2012.06.004.

16. Motzer RJ, Rini BI, McDermott DF, Redman BG, Kuzel TM, Harrison MR, Vaishampayan UN, Drabkin HA, George
S, Logan TF, Margolin KA, Plimack ER, Lambert AM, et al. Nivolumab for Metastatic Renal Cell Carcinoma: Results of a Randomized Phase II Trial. J Clin Oncol. 2015; 33:1430-7. https://doi.org/10.1200/JCO.2014.59.0703.

17. Choueiri TK, Escudier B, Powles T, Mainwaring PN, Rini BI, Donskov F, Hammers H, Hutson TE, Lee JL, Peltola K, Roth BJ, Bjarnason GA, Geczi L, et al. Cabozantinib versus Everolimus in Advanced Renal-Cell Carcinoma. N Engl J Med. 2015; 373:1814-23. https://doi. org/10.1056/NEJMoa1510016.

18. Erichsen HC, Chanock SJ. SNPs in cancer research and treatment. Br J Cancer. 2004; 90:747-51. https://doi. org/10.1038/sj.bjc.6601574.

19. Garcia-Donas J, Esteban E, Leandro-Garcia LJ, Castellano DE, del Alba AG, Climent MA, Arranz JA, Gallardo E, Puente J, Bellmunt J, Mellado B, Martinez E, Moreno F, et al. Single nucleotide polymorphism associations with response and toxic effects in patients with advanced renal-cell carcinoma treated with first-line sunitinib: a multicentre, observational, prospective study. Lancet Oncol. 2011; 12:1143-50. https:// doi.org/10.1016/S1470-2045(11)70266-2.

20. van der Veldt AA, Eechoute K, Gelderblom H, Gietema J, Guchelaar HJ, van Erp NP, van den Eertwegh AJ, Haanen JB, Mathijssen RH, Wessels JA. Genetic polymorphisms associated with a prolonged progression-free survival in patients with metastatic renal cell cancer treated with sunitinib. Clin Cancer Res. 2011; 17:620-9. https://doi. org/10.1158/1078-0432.CCR-10-1828.

21. Xu CF, Bing NX, Ball HA, Rajagopalan D, Sternberg CN, Hutson TE, de Souza P, Xue ZG, McCann L, King KS, Ragone LJ, Whittaker JC, Spraggs CF, et al. Pazopanib efficacy in renal cell carcinoma: evidence for predictive genetic markers in angiogenesis-related and exposurerelated genes. J Clin Oncol. 2011; 29:2557-64. https://doi. org/10.1200/JCO.2010.32.9110.

22. Apellaniz-Ruiz M, Diekstra MH, Roldan JM, Boven E, Castellano D, Gelderblom H, Mathijssen RHJ, Swen JJ, Bohringer S, Garcia-Donas J, Rini BI, Guchelaar HJ, Rodriguez-Antona C. Evaluation of KDR rs34231037 as a predictor of sunitinib efficacy in patients with metastatic renal cell carcinoma. Pharmacogenet Genomics. 2017; 27:227-31. https://doi.org/10.1097/FPC.0000000000000280.

23. Diekstra MH, Fritsch A, Kanefendt F, Swen JJ, Moes D, Sorgel F, Kinzig M, Stelzer C, Schindele D, Gauler T, Hauser S, Houtsma D, Roessler M, et al. Population Modeling Integrating Pharmacokinetics, Pharmacodynamics, Pharmacogenetics, and Clinical Outcome in Patients With Sunitinib-Treated Cancer. CPT Pharmacometrics Syst Pharmacol. 2017; 6:604-613. https:// doi.org/10.1002/psp4.12210.

24. van der Zanden LF, Vermeulen SH, Oskarsdottir A, Maurits JS, Diekstra MH, Ambert V, Cambon-Thomsen A, Castellano D, Fritsch A, Garcia Donas J, Guarch Troyas R, Guchelaar HJ, Hartmann A, et al. Description of the EuroTARGET cohort: A European collaborative project 
on TArgeted therapy in renal cell cancer-GEnetic- and tumor-related biomarkers for response and toxicity. Urol Oncol. 2017; 35:529.e9-529.e16. https://doi.org/10.1016/j. urolonc.2017.03.009.

25. Diekstra MH, Liu X, Swen JJ, Boven E, Castellano D, Gelderblom H, Mathijssen RH, Rodriguez-Antona C, Garcia-Donas J, Rini BI, Guchelaar HJ. Association of single nucleotide polymorphisms in IL8 and IL13 with sunitinib-induced toxicity in patients with metastatic renal cell carcinoma. Eur J Clin Pharmacol. 2015; 71:1477-84. https://doi.org/10.1007/s00228-015-1935-7.

26. Diekstra MH, Swen JJ, Boven E, Castellano D, Gelderblom H, Mathijssen RH, Rodriguez-Antona C, Garcia-Donas J, Rini BI, Guchelaar HJ. CYP3A5 and $\mathrm{ABCB} 1$ polymorphisms as predictors for sunitinib outcome in metastatic renal cell carcinoma. Eur Urol. 2015; 68:621-9. https://doi.org/10.1016/j.eururo.2015.04.018.

27. Dong G, Guo X, Fu X, Wan S, Zhou F, Myers RE, Bao G, Burkart A, Yang H, Xing J. Potentially functional genetic variants in KDR gene as prognostic markers in patients with resected colorectal cancer. Cancer Sci. 2012; 103:561-8. https://doi.org/10.1111/j.1349-7006.2011.02194.x.

28. Escudier B, Rini BI, Motzer RJ, Tarazi J, Kim S, Huang X, Rosbrook B, English PA, Loomis AK, Williams JA. Genotype Correlations With Blood Pressure and Efficacy From a Randomized Phase III Trial of Second-Line Axitinib Versus Sorafenib in Metastatic Renal Cell Carcinoma. Clin Genitourin Cancer. 2015; 13:328-37 e3. https://doi. org/10.1016/j.clgc.2015.02.007.

29. Pare-Brunet L, Sebio A, Salazar J, Berenguer-Llergo A, Rio E, Barnadas A, Baiget M, Paez D. Genetic variations in the VEGF pathway as prognostic factors in metastatic colorectal cancer patients treated with oxaliplatin-based chemotherapy. Pharmacogenomics J. 2015; 15:397-404. https://doi.org/10.1038/tpj.2015.1.

30. Zheng YB, Zhan MX, Zhao W, Liu B, Huang JW, He X, Fu SR, Zhao Y, Li Y, Hu BS, Lu LG. The relationship of kinase insert domain receptor gene polymorphisms and clinical outcome in advanced hepatocellular carcinoma patients treated with sorafenib. Med Oncol. 2014; 31: 209. https:// doi.org/10.1007/s12032-014-0209-z.

31. Scartozzi M, Bianconi M, Faloppi L, Loretelli C, Bittoni A, Del Prete M, Giampieri R, Maccaroni E, Nicoletti S, Burattini L, Minardi D, Muzzonigro G, Montironi R, et al. VEGF and VEGFR polymorphisms affect clinical outcome in advanced renal cell carcinoma patients receiving firstline sunitinib. Br J Cancer. 2013; 108:1126-32. https://doi. org/10.1038/bjc.2012.501.

32. Tu H, Li Q, Cai J, Chen Z, Yang H, Jiang H, Mao Y, Shou Z, Chen J. Extragastrointestinal stromal tumor in a kidney transplant recipient. Clin Exp Nephrol. 2012; 16:350-3. https://doi.org/10.1007/s10157-011-0550-x.

33. Longatto-Filho A, Pinheiro C, Martinho O, Moreira MA, Ribeiro LF, Queiroz GS, Schmitt FC, Baltazar F, Reis RM. Molecular characterization of EGFR,
PDGFRA and VEGFR2 in cervical adenosquamous carcinoma. BMC Cancer. 2009; 9: 212. https://doi. org/10.1186/1471-2407-9-212.

34. Bondurant KL, Lundgreen A, Herrick JS, Kadlubar S, Wolff RK, Slattery ML. Interleukin genes and associations with colon and rectal cancer risk and overall survival. Int J Cancer. 2013; 132:905-15. https://doi.org/10.1002/ ijc. 27660 .

35. Crawford DC, Nickerson DA. Definition and clinical importance of haplotypes. Annu Rev Med. 2005; 56:30320. https://doi.org/10.1146/annurev.med.56.082103.104540.

36. Dornbusch J, Walter M, Gottschalk A, Obaje A, Junker K, Ohlmann $\mathrm{CH}$, Meinhardt $\mathrm{M}$, Zacharis A, Zastrow S, Schoffer O, Grimm MO, Klug SJ, Wirth MP, et al. Evaluation of polymorphisms in angiogenesis-related genes as predictive and prognostic markers for sunitinib-treated metastatic renal cell carcinoma patients. J Cancer Res Clin Oncol. 2016; 142:1171-82. https://doi.org/10.1007/ s00432-016-2137-0.

37. Bianconi M, Faloppi L, Loretelli C, Zizzi A, Giampieri R, Bittoni A, Andrikou K, Del Prete M, Burattini L, Montironi R, Scartozzi M, Cascinu S. Angiogenesis genotyping in the selection of first-line treatment with either sunitinib or pazopanib for advanced renal cell carcinoma. Oncotarget. 2016; 7:37599-607. https://doi.org/10.18632/ oncotarget.9229.

38. Saenz-Lopez P, Vazquez F, Cozar JM, Carretero R, Garrido F, Ruiz-Cabello F. VEGF polymorphisms are not associated with an increased risk of developing renal cell carcinoma in Spanish population. Hum Immunol. 2013; 74:98-103. https://doi.org/10.1016/j.humimm.2012.10.014.

39. de Mello RA, Ferreira M, Soares-Pires F, Costa S, Cunha J, Oliveira P, Hespanhol V, Reis RM. The impact of polymorphic variations in the $5 \mathrm{p} 15,6 \mathrm{p} 12,6 \mathrm{p} 21$ and $15 \mathrm{q} 25$ Loci on the risk and prognosis of portuguese patients with non-small cell lung cancer. PLoS One. 2013; 8: e72373. https://doi.org/10.1371/journal.pone.0072373.

40. Wu LM, Xie HY, Zhou L, Yang Z, Zhang F, Zheng SS. A single nucleotide polymorphism in the vascular endothelial growth factor gene is associated with recurrence of hepatocellular carcinoma after transplantation. Arch Med Res. 2009; 40:565-70. https://doi.org/10.1016/j. arcmed.2009.07.011.

41. Lambrechts D, Thienpont B, Thuillier V, Sagaert X, Moisse M, Peuteman G, Pericay C, Folprecht G, Zalcberg J, Zilocchi C, Margherini E, Chiron M, Van Cutsem E. Evaluation of efficacy and safety markers in a phase II study of metastatic colorectal cancer treated with aflibercept in the first-line setting. Br J Cancer. 2015; 113:1027-34. https:// doi.org/10.1038/bjc.2015.329.

42. Barrett JC, Fry B, Maller J, Daly MJ. Haploview: analysis and visualization of LD and haplotype maps. Bioinformatics. 2005; 21:263-5. https://doi.org/10.1093/ bioinformatics/bth457. 